\title{
Legal Protection For Victims Of Traffic Violations That Lead To Death (Case Study On Police Traffic of Rembang)
}

\author{
Hengki Irawan ${ }^{1}$, Sri Endah Wahyuningsih ${ }^{2}$ and Jawade Hafiz ${ }^{3}$
}

Abstract. The purpose of this study is to know, shortly describe, analyze and assess the implementation, barriers, and the remedies to overcome obstacles in the legal protection for victims of traffic abuses resulting in death by Police Traffic of Rembang. The method used in this study, using a kind of sociological juridical research, analytical, descriptive, with data used are primary data and secondary data, and analyzed Qualitative. The results of this study are: (1) legal protection for victims of traffic abuses resulting in death by Police Traffic of Rembang preferably through peace settlement with restitution, (2) barriers in the legal protection for victims of terms: (a) the substance of the law: Act No.22 of 2009 and the Criminal Procedure Code has not been providing legal protection for victims and their families; (B) the legal structure: lack of personnel and infrastructure; and (c) the legal culture: the lack of public awareness; (3) the remedies to overcome these obstacles, in terms of: (a) the substantive law: consideration of material and immaterial damages the victim or the victim's family, (b) the legal structure: additional personnel and high-tech infrastructure, human resource development; and (c) legal cultures: socialization and education traffic rules, and concept of restorative justice. (A) the substantive law: consideration of material and immaterial damages the victim or the victim's family, (b) the legal structure: additional personnel and high-tech infrastructure, human resource development; and (c) legal cultures: socialization and education traffic rules, and concept of restorative justice. (A) the substantive law: consideration of material and immaterial damages the victim or the victim's family, (b) the legal structure: additional personnel and high-tech infrastructure, human resource development; and (c) legal cultures: socialization and education traffic rules, and concept of restorative justice.

Keywords: Death; Victim; Traffic; Abuse; Legal Protection.

\section{Introduction}

Transport or transport is always associated with the activity of transportation and means of transport means. Juridical understanding on the notion carriage (in the sense of transport by using the street) can refer to the Law of the Republic of Indonesia No. 22 of 2009 regarding Traffic and Road Transportation and its implementing regulations. In Act No. 22 of 2009, the term "conveyance" or in English is transportation known as "transport". 4

\footnotetext{
${ }^{1}$ Student of Master of Law, Universitas Islam Sultan Agung Semarang and Member of Indonesian Police, e-mail: hengki.irawan45@yahoo.com

${ }^{2}$ Lecturer of Master of Law, Faculty of Law, UNISSULA, Semarang

3 Lecturer of Master of Law, Faculty of Law, UNISSULA, Semarang

${ }^{4}$ Andika Wijaya, 2016, Aspek Hukum Bisnis Transportasi Jalan Online, First Edition, Jakarta: Sinar Grafika, p. 10.
} 
In general, the transport in the context of Act No. 22 of 2009 is divided into two (2) types, namely transportation of people and freight transport. The division of transport in general be transporting people and goods contained in terms of transport refers to the provisions of Article 1 paragraph 3 of Act No. 22 of 2009, that is, as the movement of people and / or goods from one place to another by using the vehicle in the traffic Street.

Many of the vehicles passing by in the road traffic, of automobiles, motorcycles, buses and trucks at a slow pace, was even faster. Not infrequently these vehicles overtaking each other at high speed to get ahead of the vehicle in front. Especially in this day and age, children are already allowed to drive a motor vehicle, without the completeness of the drive moreover letter driving license.

Many violations of driving on the highway, and a part forms of violations that often occur due to negligence, carelessness, even deliberate does not comply with the rules and pass-traffic drive. Lack of compliance and legal awareness public to less traffic, causing traffic violations that cause accidents and even death of the victim. Motorists often do not pay attention to safety for himself or others.

Here has been a violation of law or order passed traffic, namely Act No. 22 of 2009. In essence, the law has a strategic and dominant position, nation and state. Laws are made as good as any, if not complied with by governments and their peoples, then the law becomes useless to the interests of the state and citizens, ${ }^{5}$ as well as violation of the traffic rules.

The human factor is a major cause of traffic violations and accidents. The forms of traffic offenses are often carried out by people, among which are driving with no carries or does not have a driver's license (SIM), Vehicle registration number (vehicle registration), helmet, through the traffic lights, park the vehicle on-Random place, driving a motor vehicle for more than two people, using mobile phones while driving, drunk driving, and so on.

Traffic violations that lead to the fall of the victim's death is a very avoidable, because of someone's life is very precious, and disappear as a result of negligence, carelessness accidental even all others who do not abide by the rules and traffic signs.

People who cause accidents because of violations that are doing must account for his actions, with heading-an offender may be chastened and more cautious in driving so as not to harm others. Victims should also get legal protection for damages caused by the perpetrator.

Traffic violations that cause the death of the victim, obviously taking the life of others recklessly. As a form of justice and legal protection for victims, offenders should be subject to criminal in order to obtain a deterrent effect, and as an attempt to enforce

\footnotetext{
${ }^{5}$ Haafiz Jawade Arsyad and Dian Charisma, 2018, Sentralisasi Birokrasi Pengadaan Barang \& Jasa Pemerintah, First Edition, Jakarta: Sinar Grafika, p. 26.
} 
traffic regulations. Sudarto found that the criminal is suffering deliberately imposed on those who commit acts that meet certain conditions. ${ }^{6}$

Based on the above, in this study, the authors formulate the problem as follows:

- How legal protection for victims of traffic abuses resulting in death by Police Traffic of Rembang?

- What are the obstacles in the legal protection for victims of traffic abuses resulting in death by Police Traffic of Rembang?

- How are the remedies to overcome obstacles in the legal protection for victims of such abuses of traffic clicking death by Police Traffic of Rembang?

\section{Research methods}

This type of research is the socio-juridical, which examines the workings of law in society, the nature of the descriptive analytical research. The data used in the writing of this study are primary data and secondary data obtained through interviews and literature study, which was then analyzed qualitatively.

\section{Results and Discussion}

\subsection{Efforts abuses of legal protection for victims of traffic that resulted in the death by Apex Traffic Police;}

Traffic violation in the area of Rembang police station frequent and repeated for lack communities condition in Rembang, and against traffic violations that are not casualties and did not result in death of the victim then Apex Police Traffic take action in the form of a ticket and a reprimand. ${ }^{7}$

The forms of action are included in the violations found by the Police Traffic of Rembang, among others, did not bring the letters in the form of vehicles Driving License (SIM) and the Vehicle registration number (vehicle registration), motorists who do not use or wear a helmet standard helmet non-SNI, and the criminal offense of traffic, traffic accidents. ${ }^{8}$

Traffic accidents are influenced by several factors, and these factors are interrelated as the cause of the accident. One is the human factor that does not care and does not give priority to the safety of his own life by driving a vehicle with inconsiderate, driving without wearing a helmet or driving a car without a seat belt, which is where these actions not only harm themselves but also other motorists. ${ }^{9}$

\footnotetext{
${ }^{6}$ Sri Endah Wahyiningsih, 2013, Prinsip-Prinisp Individualisasi Pidana Dalam Hukum Pidana Islam dan Pembaharuan Hukum Pidana Indonesia, Second Edition, Semarang: Badan Penerbit Universitas Diponegoro, p. 80.

${ }^{7}$ Bripka Sutrisna, Interview, Traffic Police as Assistant Investigator Rembang, on February 25, 2020.

${ }^{8}$ Ibid.

${ }^{9}$ lbid.
} 
Negligence of the driver of the vehicle does things that are difficult to avoid, but the driver should always be alert when pulled the vehicle by limiting the things that could cause a traffic accident. Thus, the vehicle driver who violates traffic to cause the victim's death through negligence or mistakes included in a criminal act, and may be subject to criminal sanctions as the applicable law. ${ }^{10}$

So that the law can be enforced, the necessary instrument of state assigned the duty and responsibility to enforce the law with a certain authority, insisting that legal requirements are adhered to. This is according to Mochtar Kusumaatmadja that: "The law was without power is a chimera, while power without law is late", so for the rule of law need power to support it, and vice versa power should be limited authority under the rule of law. ${ }^{11}$

As law enforcement agencies in realizing security and order in the community, the police were those associated directly with the public. In this position, the police are expected to do much to play a role in law enforcement (law enforcement) of the communities it serves. ${ }^{12}$

At the casualty causing death, the victims here are not only the victims who suffer directly as a result of the accident, but also the families left behind. Especially if the victim is the breadwinner for her family, then as a result of traffic offenses should really get consideration from law enforcement. ${ }^{13}$

In the case of traffic accidents that cause deaths in Rembang the victim the police station, sometimes pursued through legal channels and through reconciliation between the offender and the victim's family. In sails through legal recourse for the victim's family can not accept the perpetrator's actions that cause fatalities. However, there is also the victim's family that receives the event as destiny and not prolong the problem. Of course, the families of the victims receive restitution or compensation in the form of dams the victim. ${ }^{14}$

The peace efforts can facilitate any cases and reduce the buildup of a court, and more importantly the interests of victims and their families are not neglected, as if resolved through legal channels. ${ }^{15}$

One form of protection for victims of restoring the loss suffered by the victim as the second case above is through restorative justice. The protective measures be

\footnotetext{
10 Ibid.

${ }^{11}$ Asep Supriadi, 2014, Kecelakaan Lalu Lintas dan Pertanggungjawaban Pidana Korporasi Dalam Perspektif Hukum Pidana Indonesia, First Edition, Bandung: Alumni, p. 70.

12 I Ketut Adi Purnama, 2018, Hukum Kepolisian, Sejarah dan Peran Polri Dalam Penegakan Hukum Serta Perlindungan HAM, the First Matter, Bandung: Refika Aditama, p. 61.

${ }^{13}$ Op.Cit, Bripka Sutrisna, Interview.

${ }^{14}$ Ibid.

${ }^{15}$ Ibid.
} 
interpreted where victims and their families involved in the process of completion. In restorative justice there are three (3) major issues, namely: ${ }^{16}$

- Fixing and satisfy the victims in the implementation of the criminal justice system;

- Fixing and satisfying the perpetrator;

- Fixing and satisfying the public after the process of the criminal justice system.

Legal protection of accident victims who died, more appropriately applied the concept of restorative justice compared with the legal settlement. The perpetrators to the victims and their families in restorative justice is very clear and does not lead to hostility in the future between the perpetrator and the victim's family, rather than criminal the only cause all and not necessarily a deterrent effect on perpetrators.

\subsection{Obstacles to such abuses of legal protection for victims of traffic that resulted in the death by Apex Traffic Police;}

Weaknesses in law enforcement because no operation of law in society properly. The workings of the criminal justice system is an attempt to prevent crime, it is closely associated with the criminal justice system as a system, in which has the function of social control and social maintenance.

As a system, the criminal justice system is composed of elements of the substantive law and the legal structure and legal culture. Weaknesses in these elements impact on the implementation of the law. No matter how perfect the legal substance without the support of law enforcement officials who are clean will not work if it is not supported by the legal culture of society.

Barriers to legal protection for victims of traffic that resulted in the death by Police Traffic of Rembang, can be viewed in terms of the substance of the law, the legal structure and legal culture of society, especially people in Rembang. ${ }^{17}$

- The substance of the law;

Act No. 22 of 2009 has not explicitly formulate provisions that concrete or directly providing legal protection for victims and their families, for example in the case of criminal punishment shall be considered the influence of criminal acts against the victim or their family. In addition, it is also not defined types of criminal restitution (compensation) is actually very beneficial to the victims and / or their families.

Under the draft, the provision of totally marginalized victims. KUHAP more regulating the protection of suspects, while the protection of the victim are not fully formulated. The rights granted to victims is very limited Criminal Procedure Code, which in Article 98-Article 101 Criminal Procedure Code, which regulates the mechanism of compensation of victims through the mechanism of Article 98 of the Criminal Code called merger lawsuit for damages, then under Article 108 paragraph

\footnotetext{
${ }^{16}$ Rena Yulia, 2013, Viktimologi, Perlindungan Hukum Terhadap Korban Kejahatan,, First Edition, Second Printing, Yogyakarta: Graha IImu, p. 161.

${ }^{17}$ Bripka Sutrisna, Interview, Traffic Police as Assistant Investigator Rembang, on February 25, 2020.
} 
(1) Code of Criminal Procedure, the victim only be considered as a witness or complainant alone.

- Legal structure;

In terms of legal structure, namely the Apex Police Traffic still lacks personnel and means that traffic enforcement.

- Legal culture.

Lack of public awareness in implementing legislation, especially Act No. 22 of 2009.

\subsection{The resolution attempts to overcome barriers to such abuses of legal protection for victims of traffic that resulted in the death by Police Traffic of Rembang.}

As a form of legal protection for victims, of course, the rights or interests of the victim must be restored. During this accident cases through the legal system is not effective because it has not restore the rights of victims. Sentences handed down in the form of imprisonment and / or fines. Against obstacles to such abuses of legal protection for victims of traffic that resulted in the death by Police Traffic of Rembang above efforts should be made to address them, as follows: ${ }^{18}$

- The substance of the law;

To consider the loss suffered by the victims or their families, both material and immaterial losses, so that the perpetrators could be given a criminal indemnity may be more beneficial to the victim.

- Legal structure;

The addition of personnel, human resource development, as well as the addition of adequate infrastructure and high-tech. In addition, the Traffic Unit in carrying out the functions of the Police must comply with the demands and needs of the community, is more concerned with a sense of justice to the people in general rather than enforcement of rigid law and law enforcement that much energy, so they are working to cases of traffic violations through mediation.

If the settlement is done through legal channels, the investigators provide access to the victims and their families of the judicial process. Victims are entitled to know the development of the case, especially if it deals with offenders who are not able to be responsible, then the victim is also possible to obtain compensation.

- Legal culture.

Lack of public awareness of orderly traffic can be done with the socialization and education of the public about the cultural importance of traffic rules. In addition, efforts to involve victims in the criminal justice process is important, because the relationship of victims, communities and offenders become the focus for mediation and resolve conflicts they face.

\footnotetext{
${ }^{18}$ Op.cit, Bripka Sutrisna, Interview.
} 
The most important thing is the need to resolve any criminal cases, including traffic violations through the concept of restorative justice would accelerate the settlement and provide per-protection for the rights of victims and their families.

\section{Closing}

\subsection{Conclusion}

- Efforts abuses of legal protection for victims of traffic that resulted in the death by Police Traffic of Rembang preferably settlement through peace by asking for perpetrators to victims and their families through the provision of restitution and compensation. If the peace efforts can not be done, then it will be pursued through legal channels;

- Barriers to legal protection for victims of such abuses of traffic that resulted in the death by Police Traffic of Rembang terms: (i) the substance of the law: Act No. 22 of 2009 has not explicitly formulate provisions that concretely providing legal protection for victims and their families and in the Criminal Code regarding the regulation altogether marginalized victims; (li) the legal structure: Apex Police Traffic still lacks personnel and adequate infrastructure; and (iii) the legal culture: the lack of public awareness in implementing legislation;

- The resolution attempts to overcome barriers to per-patronage law for victims of such abuses of traffic clicking death by Police Traffic of Rembang terms: (i) the substance of the law: it needs to be considered also the loss suffered by the victims or their families, both material losses and immaterial; (li) legal structures: the addition of personnel, improvement of human resources, as well as the addition of adequate infrastructure and high-tech; and (iii) the legal culture: socializing and educating the public about the cultural importance of traffic rules. In addition to this, the need for the completion of any criminal case.

\subsection{Suggestion}

- For legislators, to be more expensive per-patronage law for victims and their families in the formation of legislation criminal law;

- For law enforcement officers, more focus on supporting the settlement with the concept of restorative justice;

- For society, it is necessary to raise awareness to create an orderly environment.

\section{References}

[1] Andika Wijaya, 2016, Aspek Hukum Bisnis Transportasi Jalan Online, Jakarta: Sinar Grafika 
[2] Asep Supriadi, 2014, Kecelakaan Lalu Lintas dan Pertanggungjawaban Pidana Korporasi Dalam Perspektif Hukum Pidana Indonesia, First Edition, Bandung: Alumni

[3] I Ketut Adi Purnama, 2018, Hukum Kepolisian, Sejarah dan Peran Polri Dalam Penegakan Hukum Serta Perlindungan HAM, the First Matter, Bandung Refika Aditama

[4] Haafiz Jawade Arsyad and Dian Charisma, 2018, Sentralisasi Birokrasi Pengadaan Barang \& Jasa Pemerinta, First Edition, Jakarta; Sinar Grafika

[5] Rena Yulia, 2013, Viktimologi, Perlindungan Hukum Terhadap Korban Kejahatan, Second Printing, Yogyakarta: Graha IImu

[6] Sri Endah Wahyiningsih, 2013, Prinsip-Prinisp Individualisasi Pidana Dalam Hukum Pidana Islam dan Pembaharuan Hukum Pidana Indonesia, Second Edition, Semarang: Badan Penerbit Universitas Diponegoro 